\title{
DETERMINANTS OF BANK PROFITABILITY: THE CASE OF THE REGIONAL DEVELOPMENT BANK (BPD BANK) IN INDONESIA
}

\author{
R.A. Supriyono ${ }^{1 *}$, Heyvon Herdhayinta ${ }^{2}$ \\ ${ }^{1,2}$ Department of Accounting, Faculty of Economics and Business, Universitas Gadjah Mada, \\ Yogyakarta, 55281, Indonesia
}

\begin{tabular}{|c|c|}
\hline ABSTRACT & ARTICLE INFO \\
\hline $\begin{array}{l}\text { Introduction: The Regional Development Bank (BPD Bank) is expected } \\
\text { to be a strong, highly competitive bank, which will contribute to the } \\
\text { growth and even distribution of sustainable regional economies. } \\
\text { Background Problem: A review by the Financial Service Authority } \\
\text { (OJK) of the BPD Bank's business growth indicates the low } \\
\text { competitiveness of the BPD Bank, relative to other commercial banks. } \\
\text { Novelty: Limited prior studies have been conducted on the profitability } \\
\text { determinants of the BPD Bank, especially in Indonesia, and previous } \\
\text { studies have only focused on the internal determinants of profitability. } \\
\text { Hence, this research aims to analyze both the internal and external } \\
\text { profitability determinants of the BPD Bank in Indonesia. Research } \\
\text { Method: This study analyzes } 135 \text { observations in total from all } 27 \text { BPD } \\
\text { banks in Indonesia for five years, from } 2011 \text { to } 2015 \text {. This research } \\
\text { measured bank profitability using ROA and ROE as the dependent } \\
\text { variables. The independent variables are the internal and external } \\
\text { determinants of bank profitability. The internal determinants of } \\
\text { profitability consist of TA, TCORCAP, CAR, NPL, LDR, OE/OI and } \\
\text { NIM; whilst the external determinants include TMS, INF and BIRATE. } \\
\text { Findings: The findings of this study show that the profitability of the } \\
\text { BPD Bank, as measured by its Return on Assets (ROA) and Return on } \\
\text { Equity (ROE), is significantly determined internally by the total assets, } \\
\text { LDR, OE/OI, and NIM and externally by the BIRATE and inflation. } \\
\text { Those variables have positive relationships with profitability, except for } \\
\text { OE/OI and inflation, which have negative relationships with profitability. } \\
\text { In addition, two hypotheses are only partially supported, in which the } \\
\text { total core capital and CAR show negative relationships only with ROE. } \\
\text { Conclusion: The findings of this paper provide a deeper insight to help } \\
\text { manage the profitability of the BPD Bank, which eventually can promote } \\
\text { sustainable economic development. }\end{array}$ & $\begin{array}{l}\text { Article history: } \\
\text { Received } 23 \text { December } \\
2016 \\
\text { Received in revised form } \\
28 \text { June } 2018 \\
\text { Received in revised form } \\
1 \text { November } 2018 \\
\text { Received in revised form } \\
11 \text { March } 2019 \\
\text { Accepted } 22 \text { March } 2019 \\
\\
\text { Keywords: } \\
\text { Regional Development } \\
\text { Bank (BPD Bank), } \\
\text { profitability, Return on } \\
\text { Assets (ROA), Return on } \\
\text { Equity (ROE) }\end{array}$ \\
\hline
\end{tabular}

\footnotetext{
* Corresponding author at the Department of Accounting, Faculty of Economics and Business, Universitas Gadjah Mada, Jalan Sosio Humaniora No. 1, Yogyakarta 55182, Indonesia.

E-mail address: rasupriyono@ugm.ac.id (author\#1), heyvonh@ugm.ac.id (author\#2)
} 


\section{INTRODUCTION}

Banking is one of the main pillars of the Indonesian economy, and plays an important role as a financial intermediary. The relationship between the profitability of the banking sector and economic growth is known to be very important (Rajan \& Zingales, 1998; Levine, 1998). Banks with excellent financial performance and high levels of competitiveness could actively distribute commercial credit to the business sector, and this will significantly contribute to the rapid growth of the economy and the business environment. The determinants of bank profitability are not only crucial for bank managers, but also for other stakeholders, such as Bank Indonesia (BI), the Financial Services Authority (OJK), banker associations, and governments. These determinant factors are useful for managers and the relevant authorities to formulate future strategies and policies to improve the profitability of the banking sector in Indonesia.

Throughout time, there have been some significant changes in the banking industry in Indonesia, in response to the dynamic changing environment, for example, the deregulation of competition in the national market and internationalization. At the national level, BI and the OJK, which was previously known as the Capital Market and Financial Institution Supervisory Agency (Bapepam LK), continue to push for reformation in order to accelerate the development of the financial market, the banking and non-banking sectors, and the capital market, as alternative sources of financing. At the regional level the Association of Southeast Asian Nations (ASEAN), through the ASEAN Free Trade Agreement (AFTA), tries to encourage cross-border trade and competition in financial services, through the ASEAN Economic Community (AEC). This kind of free market cooperation is commonly found at the international level in other regions, such as the European Economic Community (EEC) and the North American Economic Alliance (NAEA). Changes at the national and international levels challenge financial institutions, including the banks in Indonesia, since their environment changes rapidly. Banks should be focused on continuous improvements in their operations and performance, to be able to compete and survive within the dynamic business environment. Those changes could influence banks' profitability, as they are required to maintain their solvency in order to survive, grow and prosper in such a competitive market.

According to their ownership, there are six categories of commercial banks in Indonesia, i.e. state-owned banks, national private foreign exchange banks, national private non-foreign exchange banks, regional development banks, joint-venture banks, and foreign banks. The Indonesian Act Number 13 of 1962 states that the Regional Development Bank (BPD Bank) is a regional development bank established by the Indonesian government to support the financing of local business development within the framework of national development planning. It is expected to be a strong highly competitive bank, able to contribute toward the growth and even distribution of sustainable regional economies. However, a review by the OJK on the BPD Bank's business growth in 2014 showed that BPD Banks in Indonesia have lower percentage of total assets, third-party funds and credit, compared to other commercial banks within this industry. As presented in Table 1, the data about the total assets, credit, and deposits of BPD Bank are relatively stagnant during 20122014 , and are $10 \%$ below the industry norm. This indicates the low competitiveness of the BPD Bank, relative to other commercial banks (OJK, 2015). This low competitiveness may cause a negative impact on businesses and 
Table 1. Share of BPD Bank compared to Industry

\begin{tabular}{lccccccccc}
\hline \multicolumn{1}{c}{ Post } & \multicolumn{3}{c}{ Total Asset } & \multicolumn{3}{c}{ Third-Party Funds } & \multicolumn{3}{c}{ Credit } \\
\hline Period & 2012 & 2013 & 2014 & 2012 & 2013 & 2014 & 2012 & 2013 & 2014 \\
Share BPD vs Industry & $8.60 \%$ & $7.87 \%$ & $7.85 \%$ & $8.64 \%$ & $7.85 \%$ & $8.17 \%$ & $8.03 \%$ & $7.97 \%$ & $8.13 \%$ \\
\hline
\end{tabular}

Source: Indonesian Banking Statistic as cited in OJK, 2015.

economic development, such as a lack of funding for local businesses, particularly the smallmedium enterprises who rely on BPD Bank.

There has been considerable research in respect of banking profitability around the world, but most of the research has been centered on commercial banking (Aburime, 2008; Bourke, 1989; Javaid, Anwar, Zaman \& Gaffor, 2011; Kasmidou, 2008; Molyneux \& Thornton, 1992; Naceur, 2003; Sufian \& Chong, 2008; Vong \& Chan, 2009). We scrutinize the profitability of regional development banks because they face different challenges compared to other commercial banks. According to the Financial Services Authority (OJK, 2015), BPD banks make a relatively lower contribution to regional development; suffer from underdeveloped governance, poor human resources, weak risk management and infrastructure; and lower competitiveness of their products and services. The Indonesian government emphasizes the need for BPD Bank's transformation, to increase its competitiveness, strengthen the bank and eventually increase its contribution to regional development. A specific study on BPD bank's performance is needed to take into account the characteristics of a regional development bank in such a context.

Limited previous research has focused on regional development banks, particularly in Indonesia. Nevertheless, the Indonesian evidence is limited to a comparison among the banks (Ch, 2017), has outdated data (Alfriska \& Haryani, 2011; Buchory, 2014) and fewer variables were examined in relation to profitability (Aryanti, 2010; Buchory, 2015; Yanuardi
\& Sumiati, 2014). Buchory (2016) examined BPD Bank's profitability, but only used the Return on Assets (ROA) as a proxy of profitability and only concentrated on internal determinants per se. This present research aims to fill the gap, and contributes to the previous literature by examining not only the internal, but also the external determinants of BPD Bank's profitability, using both the Return on Assets (ROA) and Return on Equity (ROE) as the proxies of profitability.

By analyzing data from all 27 of the BPD banks in Indonesia, this research has further relevance for policymakers, notably management and the relevant authorities, to help them derive some strategies regarding profitability. This study examines the determinants of BPD Bank's profitability during the period 20112015. Recent data are analyzed to figure out the latest developments in bank profitability determinants in Indonesia. The operation of BPD banks throughout Indonesia influences the financial markets, especially in their respective regions. BPD banks manage to raise third-party funds and distribute them in the form of credit in relatively large amounts, either to individual customers, companies or other institutions. BPD banks also concentrate on credit distribution, particularly for small-medium enterprises who rely for their businesses' funding on BPD banks. Therefore, these BPD banks play an important role in the financial markets and the economy of Indonesia.

This paper seeks to examine the profitability determinants of the BPD Bank, internally and externally; to analyze which determinants 
significantly influence the profitability, and to highlight policies regarding bank profitability for the stakeholders, especially the management and the financial authorities. The main objectives of this study are to answer the following questions:

1. What are the internal and external determinants of BPD Bank profitability, and how do they influence the profitability of BPD Bank?

2. What policies should be suggested to the stakeholders of BPD Bank, in relation to the determinants of profitability?

The first section of the paper gives an introductory overview of the research problems, contributions, objectives and research questions. The second section elaborates on the literature reviews, the formulated hypotheses and the determinants being utilized. Presented in the third section is the data and methodology, which describes the data selection process, regression model, and data's analysis. Section four analyses the result of the regression analysis. Lastly, section five draws the conclusion of the research and the suggestions proposed.

\section{LITERATURE REVIEW}

\section{Profitability}

Research into the determinants of banks' profitability have been conducted in many countries. Burki and Niazi (2003) analyzed the impact of the internal determinant of bank profitability in Pakistan using data from 40 banks for the period from 1991 to 2000 . The research found a significant positive impact on bank size (in total assets), the ratio of interest income to productive assets, and the Loan to Deposit Ratio (LDR). Javaid et al. (2011) examined the internal determinants of ten banks in Pakistan for the period 2004-2008 using the ordinary least squares method (Pooled Ordinary Least Squares- POLS). The study examined the impact of assets, equity, loans, and deposits toward bank profitability as measured by the ROA. The empirical results found strong evidence that the variables had significant effects on profitability.

Azam and Siddiqui (2012) compared the profitability of public, private, and foreign banks operating in Pakistan from 2004 to 2010. Their study measured profitability with ROA and ROE, while the profitability determinants used were divided into the internal and external variables. The internal determinants were deposits, the Capital Adequacy Ratio (CAR), Non-Performing Loan (NPL), Loan to Deposit Ratio (LDR), Operating Expenses to Operating Income (OE/OI) and Net Interest Margin (NIM), whereas the external determinants were inflation and Gross Domestic Product (GDP). The findings showed that the determinants which significantly affect ROA were OE/OI and GDP for public banks; CAR, NIM, deposits, and LDR for private banks; and OE/OI and GDP for foreign banks. Meanwhile, the factors affecting ROE were OE/OI and GDP for public banks; deposits for private banks; and CAR, NIM, $\mathrm{OE} / \mathrm{OI}$ and inflation for foreign banks.

Sufian and Chong (2008) investigated bank profitability determinants in the Philippines for the period 1990-2005. Their findings argued that internal determinants, i.e. assets, NPL, and OE/OI negatively affected bank profitability, while non-interest income and capitalization had a significant positive impact on profitability. In addition, inflation, as an external determinant, had a significant negative impact on profitability, while economic growth (measured by GDP), the money supply and stock capitalization, as the external determinants, had no significant effect in explaining bank profitability.

Kosmidou, Pasiouras, Doumpos, and Zopounidis (2004) examined the determinants of bank profitability in the UK during the period 
1995-2002 with 32 banks as their sample. The results indicated that the internal determinant, which is capital, had a significant positive effect on bank profitability, while bank size (assets) and $\mathrm{OE} / \mathrm{OI}$ had a significant negative effect on bank profitability. Internal determinants, namely NPL and CAR, had no significant effect on profitability. Meanwhile, the external determinants, i.e. GDP, inflation, market capitalization, and size positively affected bank profitability.

Another study, by Vong, and Chan (2009) studied bank profitability determinants in Macau from 1993 to 2007. It was found that the internal determinants, namely the Capital Adequacy Ratio (CAR) positively affected the banks' profitability, while loans, NPL, income taxes, and deposits negatively affected profitability. In contrast, other internal determinants such as noninterest expenses and non-interest income did not significantly affect profitability. Furthermore, inflation, as an external determinant, positively affected profitability, while the interest rate had no significant effect on profitability. Other external determinants related to financial structures such as size, GDP and Lerner index also did not significantly affect profitability.

In Indonesia, scholars have also conducted multiple studies into banks' profitability (Alfriska \& Haryani, 2011; Aryanti, 2010; Buchory 2014, 2015; Chaniago \& Widyantoro, 2017; Mawardi, 2004; Suryanto, 2015; Syamni et al., 2017; Wijaya \& Sihombing, 2015, Yanuardi \& Sumiati, 2014). Yanuardi and Sumiati (2014) analyzed the determinant factors affecting the profitability of banks listed on the Indonesian Stock Exchange (IDX) during 2010 to 2012. The result of a multiple linear regression analysis showed that the risk of credit, capital, and inflation had a significant positive effect on profitability. However, management efficiency had a significantly negative influence on bank profitability. Meanwhile, the liquidity risk and GDP did not affect profitability.

Nevertheless, there are some contested results from the studies conducted in Indonesia. Werdaningtyas (2002) and Mawardi (2004) found a significant positive effect of the Capital Adequacy Ratio (CAR) on ROA. This is in contrast with Usman (2003), who argued that the CAR had a significant negative effect. Mawardi (2004); Usman (2003); and Sudarini (2005) observed that NIM has a positive effect on ROA. On the other hand, Aryanti (2010) noted that NIM did not significantly affect ROA. In relation to the Loan to Deposit Ratio (LDR), Usman (2003) and Ariyanti (2010) stated that LDR had a significant positive impact on ROA. Meanwhile, Werdaningtyas (2002) found that LDR had no significant effect on ROA.

This present research serves to both add and nuance the existing literature within this area. Most previous studies in Indonesia concentrated only on commercial banks. There are currently inadequate prior academic studies into the BPD banks, and even less rigorous empirical evidence available on the profitability of the regional development banks in Indonesia. There is an urgent need to embark on a meaningful analysis of the BPD Bank's profitability. Previous empirical studies in Indonesia focused only on a comparison of the different types of banks (Ch, 2017), using outdated data (Alfriska \& Haryani, 2011; Buchory, 2014) and fewer profitability determinants were examined (Aryanti, 2010; Buchory, 2015; Yanuardi \& Sumiati, 2014). Buchory (2016) examined BPD Bank profitability, but only analyzed the internal determinant and only used ROA as a proxy for profitability. This study aims to fill the extant gap by analyzing both the internal and external determinants of BPD banks' profitability using ROA and ROE as the proxies of profitability. 
Many scholars use the Return on Assets (ROA) and Return on Equity (ROE) to measure bank profitability (Aburime, 2008; Azam \& Siddiqui, 2012; Bashir \& Hassan, 2003; Bourke, 1989; Demirguc-Kunt \& Huizinga, 2000; Kosmidou, 2008; Molyneux \& Thornton,1992; Naceur, 2003; Sufian \& Chong, 2008). Comparing both ROA and ROE can be beneficial because ROA indicates how management utilize the investment resources to create profit, while ROE reflects how efficiently banks invest and obtain financial resources from the market to generate profits (Azam \& Siddiqui, 2012). ROA is the ratio used to measure the ability of management in the overall gain. The greater the ratio of ROA, the greater the level of profit that the bank achieves and the better the position in terms of the use of the bank's assets. ROE on the other hand, reflects how efficient and effective the management are in utilizing funds from shareholders. Since ROA tends to be lower than ROE, banks likely utilized financial leverage massively to increase their ROE to a competitive level (Bashir \& Hassan, 2003).

Previous studies into the BPD Bank in Indonesia only used ROA to measure profitability and only focused on the internal determinant (Buchory, 2015; Buchory, 2016). This paper highlights both the internal and external determinants and their effect on ROA and ROE. Furthermore, bank profitability is a function of the internal and external determinants. Azam and Siddiqui (2012) consider macroeconomic factors to be bank profitability determinants in Pakistan. Hence, we add the external determinant to the existing internal bank profitability determinant. The internal determinant's factors are mainly influenced by strategies, policies, and management decisions. On the other hand, the external determinants of bank profitability are related to the macroeconomic circumstances and industry (Azam and Siddiqui, 2012). Those factors reflect the economic and legal environment in the country where the bank operates. The internal profitability's determinants in this study are bank size, capital, quality of assets, liquidity and efficiency; whereas the external determinants examined are the money supply, the interest rate set by Bank Indonesia and the inflation rate.

\section{Internal Determinants}

The internal determinants of bank profitability utilized in this research are bank size, capital, quality of assets, liquidity and efficiency (Azam \& Siddiqui, 2012; Buchory, 2015; Buchory, 2015). To measure the size of a bank, this study uses Total Assets (TA) as an indicator. Since the amount of TA vary widely among banks, this research uses the natural logarithm of total assets to mitigate data skewness. TA has a positive impact on bank profitability. However, the diversification of assets can affect the TA and increase the risk. The use of total assets as a proxy of bank size has been widely used by scholars such as in Athanasoglou, Delis and Staikouras (2008), Demirguc-Kunt and Huizinga (2000), Haron (2004), Naceur and Goaied (2010), and Uhomoibhi, (2008). Those studies found a significant positive correlation between bank size and ROA or ROE.

The second determinant, capital, affects banks' profitability since it is distributable as customer loans. Thus, a high or excessive core capital would cause a negative impact on profitability if it is not transfered as loans. Here, capital is measured by the Total Core Capital (TCORCAP) and the Capital Adequacy Ratio (CAR), which are calculated based on the ratio between capital and risk-weighted assets. The capital adequacy indicator refers to the amount of equity available to support the bank's business and acts as a safety net or cushion if the bank loses. Athanasoglou, Brissimis, and Delis (2005) 
and Berger (1995) observed a significant negative effect of capital on profitability.

The third determinant, asset quality, could be measured by two indicators, namely NonPerforming Loan (NPL) and loan growth. NPL is calculated based on the ratio of nonperforming loans to total loans. Credit growth is calculated based on the credit at the end of the period minus the initial credit. This research uses NPL as a proxy of the credit risk. NPL generally has a negative impact on bank profitability, due to the fact that bad loans reduce banks' profitability. Miller and Noulas (1997) stated that an increase in high-risk loans results in a decrease in profitability. Thakor (1987) also showed that the level of the provision for bad credit is an indication of a decrease in the quality of a bank's assets and signals a change in the profitability performance for the future.

Fourthly, liquidity is measured by the Loan to Deposit Ratio (LDR) which is calculated by comparing the total loans to the total deposits (Buchory, 2016). The growth of third-party funds is calculated based on the amount at the end of the period, reduced by the funds at the beginning of the period. LDR is inversely related to liquidity. Therefore, the higher the LDR, the lower the liquidity and vice versa. Furthermore, liquidity is inversely proportional to the profitability; hence the coefficient of LDR against the bank's profitability is expected to be positive.

Lastly, efficiency is measured by two indicators, namely the Net Interest Margin (NIM) and the ratio of Operating Expenses to Operating Income (OE/OI). NIM is calculated based on the net interest income divided by the average earnings of the assets. It is generally expected to have a positive effect on the profitability of a bank. Most studies on the effect of NIM toward bank profitability were focused on a particular country (Berger, 1995; Barajas,
Steiner \& Salazar 1999; Naceur and Goaied, 2001). Nevertheless, there are also studies that compared the effect in some other countries (Abreu \& Mendes, 2002; Demirguc-Kunt \& Huizinga, 1999). OE/OI, as reflected in the term, is calculated based on the ratio of operating expenses to operating income. OE/OI shows the efficiency of the bank's management and determines what strategies or opportunities could be taken by the managers. A high OE/OI indicates that the bank is less efficient. Thus, OE/OI has a negative impact on bank profitability. The higher the OE/OI, the lower the profitability of the bank. Research by Abreu and Mendes (2002) in several European countries concluded that $\mathrm{OE} / \mathrm{OI}$ has a significant negative impact on profitability. This result was in line with Bourke (1989), Molyneux and Thornton (1992), Fries and Taci (2005), Grigorian and Manole (2006).

Following the literature review as aforementioned, the hypotheses are formulated as follows:

H1a: Total Assets (TA) has a significant positive effect on ROA.

H1b: Total Assets (TA) has a significant positive effect on ROE.

H2a: Total Core Capital (TCORCAP) has a significant negative effect on ROA.

H2b: Total Core Capital (TCORCAP) has a significant negative effect on ROE

H3a: Capital Adequacy Ratio (CAR) has a significant negative effect on ROA.

H3b: Capital Adequacy Ratio (CAR) has a significant negative effect on ROE.

H4a: Non-Performing Loan (NPL) has a significant negative effect on ROA.

H4b: Non-Performing Loan (NPL) has a significant negative effect on ROE.

H5a: Loan to Deposit Ratio (LDR) has a significant positive effect on ROA. 
H5b: Loan to Deposit Ratio (LDR) has a significant positive effect on ROE.

H6a: Operating Expenses to Operating Income (OE/OI) has a significant negative effect on ROA.

H6b: Operating Expenses to Operating Income (OE/OI) has a significant negative effect on ROE.

H7a: Net Interest Margin (NIM) has a significant positive effect on ROA.

H7b: Net Interest Margin (NIM) has a significant positive effect on ROE.

\section{External Determinants}

Bank profitability is sensitive to macroeconomic circumstances. Generally, high economic growth would lead to more lending, resulting in a higher interest margin. Prior research in other countries consider macroeconomic factors to be bank profitability determinants (Azam and Siddiqui, 2012). Mamatzakis and Remoundos (2003) as well as Kosmidou (2008) investigated the money supply as a determinant of bank profitability in Greece. Staikouras and Wood (2004) argued that inflation affects banks' profitability in European countries. Vong and Chan (2009) examined the effect of interest on bank profitability in Macau.

To measure the effect of economic conditions on bank profitability, this research uses the Total Money Supply (TMS), the Inflation rate (INF), and Bank Indonesia's interest Rate (BIRATE). These three variables have been frequently used by scholars. This research expects the interest rate to have a significant positive effect on the profitability of banks. The interest rate determined by the central bank (BIRATE) in general affects a bank's loan interest rate and thereby increases the bank's profitability. The hypotheses in regards to external determinants are as follows:
H8a : Total Money Supply (TMS) has a significant positive effect on ROA.

H8b : Total Money Supply (TMS) has a significant positive effect on ROE.

H9a : Inflation rate (INF) has a significant negative effect on ROA.

H9b : Inflation rate (INF) has a significant negative effect on ROE.

H10a: BIRATE has a significant positive effect on ROA.

H10b: BIRATE has a significant positive effect on ROE.

\section{DATA AND METHODOLOGY}

\section{Data Selection}

This research investigates BPD Bank because of its existence in all the regions in Indonesia. Therefore, it plays an important role in the economy, particularly in its respective areas. Given all its combined total assets, BPD is the fourth largest bank in Indonesia. Moreover, as its role is to contribute towards the growth and even distribution of sustainable regional economies, it is important that this study can provide policy suggestions in an attempt to support regional economic development.

\section{Regression Model}

This study analyzes 135 observations in total from all 27 BPD banks in Indonesia for five years, from 2011 to 2015. Data for internal profitability, ROA and ROE, were taken from the annual reports and Infobank. Data for external determinants, such as the money supply, interest rate (BIRATE), and Inflation rate (INF) were retrieved from Bank Indonesia (BI), the Financial Services Authority (OJK), the World Bank and the Central Bureau of Statistics (BPS). This research measured bank profitability using ROA and ROE as the dependent variables. The independent variables are the internal and 
external determinants of bank profitability. The internal determinants of profitability consist of TA, TCORCAP, CAR, NPL, LDR, OE/OI and NIM; whilst the external determinants include TMS, INF and BIRATE.

Robust regression in STATA statistical software was used to analyze the data. This technique is designed to overcome the traditional limitation of the regression method. The regression equations of this study are as follows:

$$
\begin{aligned}
\mathrm{ROA}= & \alpha+\beta 1 \mathrm{TA}+\beta 2 \mathrm{TCORCAP}+\beta 3 \mathrm{CAR}+ \\
& \beta 4 \mathrm{NPL}+\beta 5 \mathrm{LDR}+\beta 6 \mathrm{OE} / \mathrm{OI}+\beta 7 \mathrm{NIM} \\
& +\beta 8 \mathrm{TMS}+\beta 9 \mathrm{INF}+\beta 10 \mathrm{BIRATE}+\varepsilon \\
\mathrm{ROE}= & \alpha+\beta 1 \mathrm{TA}+\beta 2 \mathrm{TCORCAP}+\beta 3 \mathrm{CAR}+ \\
& \beta 4 \mathrm{NPL}+\beta 5 \mathrm{LDR}+\beta 6 \mathrm{OE} / \mathrm{OI}+\beta 7 \mathrm{NIM} \\
& +\beta 8 \mathrm{TMS}+\beta 9 \mathrm{INF}+\beta 10 \mathrm{BIRATE}+\varepsilon
\end{aligned}
$$

Where,

$\begin{array}{lll}\text { ROA } & =\text { Return on Assets } \\ \text { ROE } & =\text { Return on Equity } \\ \text { TA } & =\text { Natural log of Total Assets } \\ \text { TCORCAP } & =\text { Natural log of Total Core } \\ & \text { Capital } \\ \text { CAR } & =\text { Capital Adequacy Ratio } \\ \text { NPL } & =\text { Non-Performing Loan } \\ \text { LDR } & =\text { Loan to Deposit Ratio } \\ \text { OE/OI } & =\text { Operating Expenses / } \\ & \text { Operating Income } \\ \text { NIM } & =\text { Net Interest Margin } \\ \text { TMS } & =\text { Natural log of Money Supply } \\ \text { INF } & =\text { Inflation } \\ \text { BIRATE } & =\text { Bank Indonesia Interest Rate }\end{array}$

There are seven variables used as the independent variables of the internal determinants, i.e. Total Assets (TA), Total Core Capital (TCORCAP), Capital Adequacy Ratio (CAR), Non-Performing Loan (NPL), Loan to Deposit Ratio (LDR), Operating Expenses to Operating
Income (OE/OI), and Net Interest Margin (NIM). Total assets (TA) is used to measure the bank's size; capital is quantified through its Total Core Capital (TCORCAP) and Capital Adequacy Ratio (CAR). Asset quality is measured by Non-Performing Loan (NPL) and liquidity is measured by the Loan to Deposit Ratio (LDR). In addition, there are two indicators used to measure efficiency, which are the Net Interest Margin (NIM) and Operating Expenses to Operating Income ratio (OE/OI). Macroeconomic factors are the external determinants of bank profitability. Generally, high economic growth would encourage banks to lend more and allow them to earn a higher interest margin, and improve the quality of their assets. The operational definition of the variables are as follows (Table 2).

\section{DATA ANALYSIS}

\section{Descriptive Statistics Analysis}

Descriptive statistics of the sample are presented in Table 3. The data is for a period of five years, from 2011 to 2015. This research uses the natural logarithms of total assets and core capital. The minimum asset is Rp1,147,175 million, while the maximum is Rp88,697,430 million and the average is Rp14,886,492 million, with a standard deviation of Rp14,953,343 million. Furthermore, the minimum core capital is Rp188,722 million, the maximum is Rp6,988,357 million and the average Rp1,478,520 million with a standard deviation of Rp1,379,421 million. Based on the standard deviation of the total assets and core capital, there are big differences between small regional development banks and large regional development banks. Other data are presented in Table 3 below. 
Table 2. Operational definitions of variables

\begin{tabular}{ll}
\hline \multicolumn{1}{c}{ Variables } & \multicolumn{1}{c}{ Operational Definitions } \\
\hline $\begin{array}{l}\text { Dependent Variables } \\
\text { Return on Assets (ROA) } \\
\text { Return on Equity (ROE) }\end{array}$ & $\begin{array}{l}\text { Ratio of net income to average total assets } \\
\text { Ratio of net income to average equity }\end{array}$ \\
$\begin{array}{l}\text { Internal Determinants } \\
\text { Total Assets (TA) }\end{array}$ & Natural logarithm of total assets \\
Total Core Capital(TCORCAP) & Natural logarithm of total core capital \\
Capital Adequacy Ratio (CAR) & Ratio of capital to Risk-Weighted Assets (RWA) \\
Non-Performing Loan (NPL) & Ratio of non-performing loan to total loan \\
Loan to Deposit Ratio (LDR) & Total loan to total funds collected \\
Net Interest Margin (NIM) & Net interest income divided by average earning assets \\
Operating Expenses to Operating Income ratio (OE/OI) & Ratio of operating expenses to operating income \\
External Determinants & \\
Total Money Supply (TMS) & Annual total of money supply \\
Inflation rate (INF) & Annual inflation rate \\
Bank Indonesia's interest Rate (BIRATE) & Annual BI rate \\
\hline
\end{tabular}

Table 3. Descriptive Statistics of BPD Bank

\begin{tabular}{lcrrrrr}
\hline \multicolumn{1}{c}{ Variables } & $\mathrm{N}$ & \multicolumn{1}{c}{ Minimum } & \multicolumn{1}{c}{ Maximum } & \multicolumn{1}{c}{ Mean } & BI Standard & \multicolumn{1}{c}{ Std. Dev. } \\
\hline Asset (Millions Rp) & 135 & $1,147,175$ & $88,697,430$ & $14,886,492$ & - & $14,953,343$ \\
Core Capital (Millions Rp) & 135 & 188,722 & $6,988,357$ & $1,478,520$ & - & $1,379,421$ \\
CAR & 135 & 9.570 & 32.290 & 19.159 & $8 \% \geq$ & 4.505 \\
NPL & 135 & 0.150 & 10.360 & 2.429 & $\leq 5 \%$ & 2.189 \\
LDR & 135 & 48.010 & 128.430 & 89.325 & $78 \%-100 \%$ & 13.895 \\
OE/OI & 135 & 54.450 & 99.560 & 74.329 & $\leq 92 \%$ & 7.910 \\
NIM & 135 & 4.950 & 15.100 & 8.023 & $\leq 5 \%$ & 1.634 \\
ROA & 135 & 0.010 & 7.440 & 3.047 & $1.5 \% \geq$ & 1.086 \\
ROE & 135 & -0.360 & 41.730 & 23.752 & $7 \% \geq$ & 8.334 \\
\hline
\end{tabular}

Notes: This table provides descriptive statistics of the sample. Total assets and total core capital are in millions of rupiah. CAR is calculated based on the ratio of capital to risk-weighted assets. NPL is calculated based on the ratio of nonperforming loan to total loans. LDR is measured by the total loans to the total funds collected. NIM is calculated based on the net interest income divided by the average earnings of the assets and OE/OI, is calculated based on the ratio of operating expenses to operating income. BI standard is given as a comparison.

Bank Indonesia categorizes banks in Indonesia into four books based on their core capital, namely Book 4 (over 30 trillion rupiah), Book 3 (5 trillion to 30 trillion rupiah), Book 2 (1 trillion to 5 trillion rupiah), and Book 1 (below 1 trillion rupiah). BPD Bank, as our sample, is divided into those categories seen in the following Table 4. The table shows the comparison and the growth of BPD banks in 2011 and 2015. The changes show that Book 3 increased from 1 to 3 banks, Book 2 increased from 14 to 15 banks, and Book 1 decreased from 12 to 9 banks. As per the end of 2015, there is no BPD bank in Book 4.

Table 4. BPD based on Core Capital

\begin{tabular}{lcc}
\hline \multirow{2}{*}{ Book } & \multicolumn{2}{c}{ Numbers of Bank } \\
\cline { 2 - 3 } & 2011 & 2015 \\
\hline Four (4): $\geq 30$ T rupiah & 0 & 0 \\
Three (3): 5 T $<$ 30T rupiah & 1 & 3 \\
Two (2): 1T $<$ 30T rupiah & 14 & 15 \\
One (1): $<$ 1T rupiah & 12 & 9 \\
Total number of bank & 27 & 27 \\
\hline
\end{tabular}


The minimum CAR of our sample is $9.570 \%$, with a maximum of $32.290 \%$, a mean of $29.159 \%$, and the standard deviation is $4.505 \%$. The minimum CAR set by the banking authority is $8 \%$ so that means all our sample meets the minimum standard. The minimum NPL is $0.150 \%$, with the maximum being $10.360 \%$, the average $2.429 \%$, and the standard deviation $2.189 \%$. The majority of banks in our sample meet the maximum NPL\% set by the banking authority, which is $5 \%$. However, some banks exceed these criteria; hence this can be a subject for attention by the banks' management and the banking regulator. The maximum LDR is $48.010 \%$, with a maximum of $128.430 \%$, an average of $89.325 \%$, and a standard deviation of $89.325 \%$. The banking authority sets the standard of LDR between $78 \%-100 \%$, thus most of our sample are still within that criteria.

Further, the minimum $\mathrm{OE} / \mathrm{OI}$ is $54.450 \%$, with a maximum of $99.560 \%$, an average of $74.329 \%$, and a standard deviation of $7.910 \%$. The Indonesian banking authority expects the banks' OE/OI not to exceed $92 \%$ and some of our sample reach that maximum. If the $\mathrm{OE} / \mathrm{OI}$ is above the standard, this means the bank's operation is less efficient and needs to be improved by both the management and the regulator. The high $\mathrm{OE} / \mathrm{OI}$ can be caused by the competitiveness of Indonesian banks in the global market. The minimum NIM is $4.950 \%$, with a maximum of $15.100 \%$, an average of $8.023 \%$, and a standard deviation of $1.634 \%$. Banking authorities set the standard for NIM at under $5 \%$. This means the majority of our sample exceeds the standard.

The data of the external determinants of profitability are shown in Table 5. The total money supply, inflation, and BIRATE, from year to year change respectively as follows (Table 5).

In addition, the minimum of ROA is $0.010 \%$, with a maximum of $7.44 \%$, an average of $3.047 \%$, and a standard deviation of $1.086 \%$. The ROA, as expected by the banking authority, is $1.5 \%$. This means the ROA of our sample are beyond expectation. Besides, the minimum ROE is $-0.360 \%$, with a maximum of $41.730 \%$, an average of $23.752 \%$, and a standard deviation of $8.334 \%$. The expected standard is $7 \%$ and most of our sample exceeds the minimum standard. A low level of ROA and ROE can affect the BPD Bank's competitiveness in the global market and can lead to a negative impact on the Indonesian economy.

Bank Indonesia, the banking authority, has assessed these BPD banks, based on their financial and other performances, and ranked them from the best to the worst since 2013. This was expected to encourage a better performance by the BPD banks. There are several performance indicators, such as a core capital of at least 1 trillion-rupiah, a Capital Adequacy Ratio (CAR) of $15 \%$, Return on Assets (ROA) of $2.5 \%$, Operating Expenses to Operating Income ratio (OE/OI) of $75 \%$, and a Net Interest Margin (NIM) of $5 \%$.

Table 5. External Profitability Determinants of BPD Bank Years 2011-2015

\begin{tabular}{cccc}
\hline Year & Total of Money Supply (in million Rp) & Inflation (\%) & BIRATE (\%) \\
\hline 2011 & $2,571,164$ & 3.79 & 6.59 \\
2012 & $3,021,437$ & 4.30 & 5.77 \\
2013 & $3,465,392$ & 8.38 & 6.48 \\
2014 & $3,867,679$ & 8.36 & 7.54 \\
2015 & $4,292,438$ & 3.35 & 7.53 \\
\hline
\end{tabular}




\section{Partial Correlation Analysis}

A partial correlations analysis is shown in Table 6. The Pearson correlation analysis between the dependent variable and the independent variable shows that the CAR, NPL, OE/OI, TA, and TCORCAP have significant negative partial correlations with ROA, while NIM and LDR have significant positive partial correlations with ROA. For the external determinant of profitability, the interest rate (BIRATE) and total money supply (TMS) have significant negative partial correlations, while inflation has no significant partial correlation with ROA.

The Pearson correlation analysis for ROE shows that the CAR, NPL, TCORCAP and OE/OI have significant negative partial correlations with ROE, while NIM has a significant positive partial correlation with ROE. In addition, the interest rate (BIRATE) and total money supply (TMS) have partial negative correlations with ROE, while inflation has no significant partial correlation with ROE.

\section{Hypotheses Testing}

Regression analysis are performed using robust regression STATA and the results are as follows.
Table 7 shows the internal and external profitability determinants of a regional development bank in Indonesia. In the first regression, ROA is the dependent variable. The results for the internal determinants show that total assets, NPL, LDR, and NIM have positive relationships while $\mathrm{OE} / \mathrm{OI}$ has a negative relationship with ROA, as the proxy of profitability. On the other hand, for the external determinants, the results show that the BI rate has a positive relationship, while inflation and the total money supply have negative relationships with profitability.

In addition, ROE is the dependent variable for the second regression. Based on the regression analysis, total assets, LDR and NIM are the internal determinants that have positive relationships with ROE as a proxy of profitability. Meanwhile, total core capital, CAR and $\mathrm{OE} / \mathrm{OI}$ are the internal determinants that have negative relationships with ROE. Furthermore, for the external determinants, inflation shows a negative relationship, while the BI rate shows a positive relationship with ROE as a proxy of profitability.

Table 6. Partial correlation (Pearson) ROA and ROE, $\mathrm{n}=135$

\begin{tabular}{lcc}
\hline \multicolumn{1}{c}{ Variable } & ROA & ROE \\
\hline INTERNAL DETERMINANTS: & & \\
CAR & $-0.167^{* *}$ & $-0.264^{* * *}$ \\
NPL & $-0.431^{* * *}$ & $-0.498^{* * *}$ \\
LDR & $0.149^{* *}$ & 0.104 \\
OE/OI & $-0.819^{* * *}$ & $-0.645^{* * *}$ \\
NIM & $0.597^{* * *}$ & $0.427^{* * *}$ \\
TA & $-0.284^{* * *}$ & -0.093 \\
TCORCAP & $-0.236^{* * *}$ & $-0.203^{*}$ \\
EXTERNAL DETERMINANTS: & & \\
INFLATION & 0.032 & 0.004 \\
BIRATE & $-0.130^{*}$ & $-0.224^{* * *}$ \\
TMS & $-0.193^{* *}$ & $-0.220^{* * *}$
\end{tabular}

Notes: This table provides the results of a partial or Pearson correlation analysis of ROA and ROE as a proxy of profitability and profitability's determinants, namely: TA, TCORCAP, CAR, NPL, LDR OE/OI, NIM, INFLATION, BIRATE and TMS. $* * * * *$ and $*$ denote significance levels at the $1 \%, 5 \%$ and $10 \%$ respectively. 
Table 7. Multivariate regression results ROA and ROE

\begin{tabular}{lrr}
\hline \multicolumn{1}{c}{ Variables } & ROA (Sig.) & ROE (Sig.) \\
\hline LNASSET & 0.443 & 19.283 \\
LNTCC & $1.91^{* *}$ & $8.85^{* * *}$ \\
& -0.376 & -19.391 \\
CAR & -1.61 & $-8.36^{* * *}$ \\
& -0.010 & -0.254 \\
NPL & -0.72 & $-1.71^{*}$ \\
& 0.036 & 0.050 \\
LDR & $1.62^{*}$ & 0.37 \\
& 0.016 & 0.183 \\
OE/OI & $5.06^{* * *}$ & $6.59^{* * *}$ \\
& -0.122 & -0.093 \\
NIM & $-22.44^{* * *}$ & $-14.73^{* * *}$ \\
& 0.164 & 0.470 \\
LNTMS & $4.69^{* * *}$ & $1.61 *$ \\
& -0.716 & -3.049 \\
INFLATION & $-2.59^{* * *}$ & -1.04 \\
& -0.038 & -0.530 \\
BIRATE & $-2.86^{* * *}$ & $-4.56^{* * *}$ \\
& 0.160 & 1.148 \\
\hline F & $2.43^{* * *}$ & $1.86^{*}$ \\
Sig. of F Test & 107.02 & 88.46 \\
R-squared & 0.000 & 0.000 \\
Number of observation & 0.902 & 0.848 \\
\hline
\end{tabular}

Notes: This table examines the relationship of bank profitability and its determinants. In the first and second regression respectively, ROA and ROE are regressed against $\mathrm{LN}$ total assets, $\mathrm{LN}$ total core capital, CAR, NPL, LDR OE/OI, NIM, INFLATION, BIRATE and LN total money supply. Coefficients of the independent variables are presented in the first row while the second row is the t-statistics. The probability of the t-statistics are as follows: ***,** and * denote significance levels at the $1 \%, 5 \%$ and $10 \%$ respectively.

The multivariate correlation (R-squared) are 0.902 and 0.848 respectively with ROA and $\mathrm{ROE}$ as the dependent variables. The $\mathrm{F}$ values are 107.02 and 88.46 respectively for the two regressions and they are statistically significant. Based on the results of the data analysis, H1a and $\mathrm{H} 1 \mathrm{~b}$ are supported, in which total assets has a positive effect on ROA $(\beta=0.443, t=1.91)$ and $\operatorname{ROE}(\beta=19.283, \mathrm{t}=8.85)$ at a significance level of $5 \%$ and $1 \%$ respectively. This result is consistent with Athanasoglou et al., (2008), Demirguc-Kunt and Huizinga (2000), Haron (2004), Naceur and Goaied (2010), and Uhomoibhi, (2008).

In addition, $\mathrm{H} 2 \mathrm{~b}$ and $\mathrm{H} 3 \mathrm{~b}$ are also supported, in which total core capital $(\beta=-19.391, \mathrm{t}=-8.36)$ and the capital adequacy ratio $(\beta=-0.254, t=$ -1.71) have a negative effect on ROE, at a significance level of $1 \%$ and $10 \%$ respectively. Our findings for the negative effect of total core capital and CAR to ROE are consistent with Athanasoglou et al., (2005) and Berger (1995). Further, H5a, H5b, H6a and H6b are supported at the $1 \%$ level of significance. This means LDR shows a positive effect on ROA ( $\beta=0.016, t=$ 5.06) and $\operatorname{ROE}(\beta=0.183, t=6.59)$. Meanwhile, OE/OI has a negative effect on ROA $(\beta=$ $0.122, \mathrm{t}=-22.44)$ and $\operatorname{ROE}(\beta=-0.093, \mathrm{t}=$ 14.73). The negative impact of $\mathrm{OE} / \mathrm{OI}$ on profitability is in line with Abreu and Mendes (2002), Bourke (1989), Molyneux and Thornton (1992), Fries and Taci (2005), Grigorian and Manole (2006). Additionally, $\mathrm{H} 7 \mathrm{a}$ and $\mathrm{H} 7 \mathrm{~b}$ are also supported at the $1 \%$ and $10 \%$ levels of significance, in which NIM has a positive effect on ROA $(\beta=0.164, \mathrm{t}=4.69)$ and $\operatorname{ROE}(\beta=$ $0.470, \mathrm{t}=1.61)$. This is in line with Berger, (1995); Barajas et al., (1999); and Naceur and Goaied, (2001).

Furthermore, for the external determinants of profitability, $\mathrm{H} 8$ is not supported, because even though the result is significant for ROA, it shows a different direction. The total money supply shows a negative correlation with ROA while it was expected to be positive. Finally, H9a, H9b, $\mathrm{H} 10 \mathrm{a}$ and $\mathrm{H} 10 \mathrm{~b}$ are supported. Inflation has a significant negative effect at the $1 \%$ level on ROA with $\beta=-0.038, t=-2.86$ and on ROE with $\beta=-0.530, t=-4.56$. Finally, the BI rate has a significant positive effect at the $1 \%$ and $10 \%$ 
levels respectively on $\mathrm{ROA}(\beta=0.160, \mathrm{t}=2.43)$ and $\operatorname{ROE}(\beta=1.148, \mathrm{t}=1.86)$.

\section{CONCLUSION AND SUGGESTIONS}

This research provides empirical evidence of the profitability determinants of regional development banks in Indonesia. Our findings indicate that the profitability of a regional development bank is significantly determined internally by its Total Assets (TA), Loan to Deposit Ratio (LDR), Operating Expenses to Operating Income ratio (OE/OI) and Net Interest Margin (NIM) and externally by the central bank's rate and the Inflation rate (INF). Those variables have positive relationships with profitability, except for the OE/OI ratio and the INF that both have a negative relationship with ROA and ROE as the proxies of profitability. Furthermore, our findings also reveal that some of our hypotheses are only partially supported; Total Core Capital (TCORCAP) and Capital Adequacy Ratio (CAR) show a negative relationship with ROE only.

Based on the data's analysis, this research highlights several recommendations for policy makers, namely: (1) The gap in terms of their total assets and total core capital among regional development banks in Indonesia is relatively high, so that the BPD Bank should maintain an optimal ratio for both the total assets and core capital. (2) Some ratios need to be improved to increase bank performance. For example, several banks have a loan to deposit ratio below Bank Indonesia's standard, as well as having nonperforming loan and operating expense to operating income ratios above the maximum stated by Bank Indonesia. BPD Bank should maintain a higher LDR ratio and lower OE/OI ratio because a higher LDR ratio and lower OE/OI ratio will enhance its profitability. (3) Some banks perform poorly, as shown by their low ROA and even negative value for ROE. This condition needs special attention especially with regard to the banks' survivability and the stability of the banking sector in general.

Finally, this study has some limitations that may be overcome in future empirical studies. We are concerned with the collinearity of the total assets and total core capital, as they are related, but we need to maintain both variables because they represent different purposes, acting as the proxies for size and capital. Core capital affects profitability as it is distributable as customer loans. A high core capital would cause a negative impact on profitability if it is not transfered as loans. Future research can conduct further analysis about bank profitability and its determinants. Future studies may consider an alternative proxy for bank profitability, such as economic value added (EVA) or the profit margin as a proxy of profitability. EVA is an alternative for measuring financial performance, reflecting economic profit after eliminating the cost of capital.

\section{REFERENCES}

Abreu, M., \& Mendes, V. (2002). Commercial bank interest margins and profitability: Evidence from E.U countries. (Porto Working Paper Series). Retrieved from https://www.researchgate.net/publication/23 7460076_COMMERCIAL_BANK_INTER EST_MARGINS_AND_PROFITABILITY EVIDENCE_FOR_SOME_EU_COUNTR IES

Aburime, T. (2008). Determinants of Bank Profitability: Macroeconomic evidence from Nigeria. (Working Paper Department of Banking and Finance, University of Nigeria). Retrieved from http://papers.ssrn.com/sol3/papers.cfm?abstr act_id=1231064

Alfriska, M., \& Haryani, S. (2011, May). Regional development banks performance in Indonesia. In The First International Credit Union Conference on Social 
Microfinance and Community Development, BKCU Kalimantan-Gunadarma University. Universitas Gunadarma.

Aryanti, L. (2010). Effect of CAR, NIM, LDR, ROA, ROA and quality earning assets gain on changes in commercial banks in Indonesia. (Master's thesis, Diponegoro University, Semarang, Indonesia). Retrieved from http://eprints.undip.ac.id/24275/

Athanasoglou, P.P., Delis, M.D., \& Staikouras, C.K. (2008). Determinants of bank profitability in the South Eastern Europe region. (Munich Personal RePEc Archive, No 10274). Retrieved from https://mpra.ub.uni-muenchen.de/10274/

Athanasoglou, P.P., Brissimis, S.N., \& Delis, M.D. (2005). Bank-specific, industryspecific and macroeconomic determinants of Bank Profitability. (Working Paper No. 25, Bank of Greece). Retrieved from https:// ideas.repec.org/p/bog/wpaper/25.html

Azam, M., \& Siddiqui, S. (2012). Domestic and foreign banks' profitability: Differences and their determinants. International Journal of Economics and Financial, 2(1), 33-40.

Barajas, A., Steiner, R., \& Salazar, N. (1999), Interest spreads in banking in Colombia 1974-1996. (IMF Staff Papers: 196-224). Retrieved from https://www.imf.org/external/Pubs/FT/staffp / 1999/06-99/barajas.htm

Bashir, A.M., \& Hassan, M.K. (2003). Determinants of Islamic banking profitability. Presented on the ERF 10th Annual Conference. Retrieved from https://www.erf.org.eg/tenthconf/Financial _Markets_Presented/Kabir_Bashir.pdf

Berger, A.N. (1995). The relationship between capital and earnings in banking. Journal of Money, Credit and Banking, 27(2), 432-456.

Bourke, P. (1989). Concentration and other determinants of bank profitability in Europe, North America and Australia. Journal of Banking and Finance, 13, 65-79.

Buchory, H.A. (2014). Analysis of the effect of capital, credit risk and profitability on the implementation of a banking intermediation function (Study on Regional Development Bank All Over Indonesia Year 2012). International Journal of Business, Economics and Law, 4(1), 133-144.

Buchory, H.A. (2015). Banking intermediation, operational efficiency and credit risk in banking profitability. International Journal of Business, Economics and Law, 7(2), 5763.

Buchory, H.A. (2016). Determinants of banking profitability in Indonesian regional development banks. Actual Problems in Economics, 177, 303-318.

Burki, A.A., \& Niazi, G.S.K. (2003). The effects of privatization, competition and regulation of banking efficiency in Pakistan, 19912000. Presented at CRC Conference, University of Manchester, UK. Retrieved from

https://www.researchgate.net/publication/25 7356667_The_Effects_of_Privatization Competition_and_Regulation_on_Banking Efficiency_in_Pakistan_1991_-_2000

Chaniago, H., \& Widyantoro, H. (2017). RBBR model: A prediction model of bank health levels based on risk for Regional Development Banks (BPD) in Indonesia. Journal of Economics, Business, and Accountancy Ventura, 20(1), 47-60.

Ch, I. (2017). The banks' rating analysis (The differences between the regional development banks and non-foreign exchange commercial banks in Indonesia). International Journal of Scientific and Technology Research, 6(6), 179-186.

Demirguc-Kunt, A., \& Huizinga, H. (1999), Determinants of commercial bank interest margins and profitability: Some international evidence. The World Bank Economic Review, 13(2), 379-408.

Demirguc-Kunt, A., \& Huizinga, H. (2000). Financial structure and bank profitability. World Bank Policy Research WP 2430). Retrieved from http://siteresources.worldbank.org/INTFR/R 
esources/475459-1108132178926/Kunt Huizinga.pdf

Fries, S., \& Taci, A. (2005). Cost efficiency of banks in transition: Evidence from 289 banks in 15 post-communist countries. Journal of Banking \& Finance, Elsevier, 29(1), 55-81.

Grigorian, D., \& Manole, V. (2006). Determinants of commercial bank performance in transition: An application of data envelopment analysis. Comparative Economic Studies, 48 (3), 497-522.

Haron, S. (2004). Determinants of Islamic banks' profitability. The Global Journal of Finance and Economics, 01(01), 2-18.

Javaid, S., Anwar, J., Zaman, K., \& Gaffor, A. (2011). Determinants of bank profitability in Pakistan: Internal factor analysis. Mediterranean Journal of Social Sciences, 2(1), 59-78.

Kosmidou, K., Pasiouras, F., Doumpos, M., \& Zopounidis, C., (2004). Foreign versus domestic banks performance in the UK: A multicriteria approach. Computational Management Science, 1(34), 329-343.

Kosmidou, K. (2008). The determinants of banks' profits in Greece during the period of EU financial integration. Managerial Finance, 34(3), 146-159.

Levine, R. (1998). The legal environment, banks, and long-run economic growth. Journal of Money, Credit and Banking, 30, 596-613.

Mamatzakis, E. C. \& Remoundos, P. C. (2003), Determinants of Greek commercial banks profitability 1989 - 2000. SPOUDAI, 53(1), 94-94.

Mawardi. (2004). The analysis of factors-factors influencing commercial bank financial performance. (Master Thesis, Universitas Diponegoro, Semarang, Indonesia). Retrieved from http://eprints.undip.ac.id/10135/

Miller, S., \& Noulas, A. (1997). Portfolio mix and large-bank profitability in the USA. Applied Economics, 29, 505-512.
Molyneux, P., \& Thornton, J. (1992). Determinants of European banks' profitability: A note. Journal of Banking and Finance, 16, 1173-1178.

Naceur, S.B. (2003). The determinants of the Tunisian banking industry profitability: Evidence panel. (Université Libre de Tunis: Department of Finance). Retrieved from http://www.mafhoum.com/press6/174E11.p df

Naceur, S.B., \& Goaied, M. (2001). The determinants of the Tunisian deposit banks' performance. Applied Financial Economics, $11,317-319$.

Naceur, S.B., \& Goaied, M. (2010). The determinants of commercial banks' interest margins and profitability: Evidences from Tansania. Jornal of Frontiers in Economics and Finance, 1(11), 317-319.

Otoritas Jasa Keuangan (OJK). (2015). Overview BPD bank's business growth year 2014. Retrieved from https://www.ojk.go.id/ id/kanal/perbankan/berita-dan-kegiatan/ publikasi/Pages/Tinjauan-BankPembangunan-Daerah-2014.aspx

Otoritas Jasa Keuangan (OJK). (2015). BPD transformation program: Becoming competitive, strong and contributive bank for regional development. Retrieved from https://www.ojk.go.id/id/kanal/perbankan/ berita-dan-kegiatan/publikasi/Pages/ Program-Transformasi-BPD.aspx

Rajan, R.G., \& Zingales, L. (1998). Financial dependence and growth. American Economic Review, 88, 559-586.

Staikouras, C., \& Wood, G., (2004). The determinants of European bank profitability. International Business and Economics Research Journal, 3(6), 57-68.

Sufian, F., \& Chong, R.R. (2008). Determinants of bank profitability in a developing country: Empirical evidence from the Philippines. Asian Academy of Management Journal of Accounting and Finance (AAMJAF, 4(2), 91-112. 
Sudarini. (2005). Use of financial ratios in predicting profit on the future. Journal Akuntansi.Vol.XVI.No. 3. December.

Suryanto. (2015). Non-performing loans of the regional development bank in Indonesia and factors that influence this. Mediterranian Journal of Social Science, 6(4), 280-287.

Syamni, G., Musnadi, S., \& Faisal. (2017). The prime lending rate and profitability of regional banks in Indonesia. Advance Science Letter, 23, 8044-8066.

Thakor, A. (1987). Asset writedowns: Managerial incentives and security returns: Discussion. Journal of Finance, 42, 661-663.

Uhomoibhi, T. (2008). Determinants of bank profitability: Macro economic evidence from Nigeria. (Working Paper, Deakin University).

Usman, B. (2003). Financial ratio analysis in predicting earnings changes in banks in
Indonesia. Media Business Research and Management, 3(1), 59-74.

Vong, P.I., \& Chan, H.S. (2009). Determinants of bank profitability in Macau. Macau Monetary Research Bulletin, 12(6), 93-113.

Werdaningtyas, H. (2002). Factors that affect the profitability of banking take-overs in Indonesia. (Master thesis, Universitas Diponogoro, Semarang, Indonesia).

Wijaya, R.D., \& Sihombing, P. (2015). Determinants of bank profitability performance: CASE STUDY of a bank registered in Kompas index bank 100 year 2009-2012. Journal of Business Strategy and Execution, 7(2), 206-235.

Yanuardi, A., \& Sumiati, D.H. (2014). Determinant factor for the profitability of banks listed on the Indonesian Stock Exchange. Journal of Accounting Multiparadigma JAMAL, 5(2), 170-274. 